УДК 351:004

DOI: $10.31891 / 2307-5740-2021-300-6 / 2-44$

КРАВЧЕНКО О. В.

ORCID ID: 0000-0001-5927-8814

e-mail: e.kravchenko@uabs.sumdu.edu.ua

ШАПОВАЛ О. Б.

ORCID ID: 0000-0003-0557-3214

e-mail: shapoval.aleksei21@gmail.com

Сумський державний університет

НЕБАБА Н. О.

ORCID ID: 0000-0003-1264-106X

e-mail: nebabanatali@meta.ua

БOTBIHOB P. $\Gamma$.

ORCID ID: 0000-0002-5865-2680

e-mail: pravda.0050@gmail.com

Університет митної справи та фінансів

\title{
БЛОКЧЕЙН-ТЕХНОЛОГЇ: СТАН ТА ПЕРСПЕКТИВИ РОЗВИТКУ В УКРАЇНІ
}

\begin{abstract}
У статті досліджено питання виникнення та розвитку технології розподіленого реєстру - блокчейн. Наведено зарубіжний досвід використання блокчейн-технології різними країнами: США, Естонія, Німеччина, Японія, Великобританія, OAE. Досліджено вплив технології блокчейн на різні галузі та сфери діяльності. Проаналізовано історичні аспекти розвитку цієї технології в Україні. Визначено основні переваги та недоліки, існуючі проблеми, перспективи розвитку та основні вітчизняні проєкти з використанням блокчейн-технології. Проведено аналіз пошукових запитів користувачів в мережі Інтернет, який дозволив зробити висновок про посилення інтересу до цієї теми в останній час. Задля визначення подальших перспектив використання блокчейн-технологій в Україні проведено SWOT-аналіз: наведено основні сильні та слабкі сторони застосування блокчейну в різних сферах, охарактеризовано його потенційні можливості та загрози.

Ключові слова: управління, криптовалюта, біткоїн, блокчейн, технологія, цифровізація, проєкти.
\end{abstract}

OLENA KRAVCHENKO, OLEKSII SHAPOVAL

Sumy State University

NATALIA NEBABA, ROSTISLAV BOTVINOV

University of Customs and Finance

\section{BLOCKCHAIN-TECHNOLOGIES: STATE AND PROSPECTS OF DEVELOPMENT IN UKRAINE}

The article investigates the origin and development of distributed registry technology - blockchain. It serves as a database and is a reliable form of information storage. The global application of blockchain technology is widespread.

Such countries using blockchain as USA, Estonia, Germany, Japan, Great Britain, UAE were analyzed. The technology is used in various industries and spheres of activity: public administration, non-cash payments, financial and production activities, the sphere of various professional services, the sphere of social security, etc. This allows to simplify activities and improve the level of state development.

Ukraine is one of the countries that use blockchain technologies and one of those, where these technologies are used at the state level. The most commonly used blockchain in the field of high-tech enterprises (Fintech), at the household level, the blockchain is closely linked to the circulation of cryptocurrencies. Today there are about a hundred companies and projects in the blockchain industry of Ukraine. Among the main projects using this technology are: electronic land auctions, the activity of the State Land Cadaster, the State Register of Real Property Rights and the System of electronic trade in seized property.

The main advantages and disadvantages, existing problems, prospects for development, and domestic projects using blockchain technology in Ukraine are identified.

Analyzing users' search queries on the Internet allowed us to conclude the growing interest in these last hours. SWOT analysis was conducted to determine further prospects for the use of the blockchain in Ukraine: the main strengths and weaknesses of the use of the blockchain in various fields are identified, and its potential opportunities and threats are described.

Keywords: management, cryptocurrency, bitcoin, blockchain, technology, digitalization, projects.

\section{Постановка проблеми у загальному вигляді}

\section{та її зв'язок із важливими науковими чи практичними завданнями}

Постійне зростання рівня конкуренції на ринку, розвиток інформаційних та комунікаційних технологій, різка диференціація потреб населення спонукає світ та провідні компанії до пошуку нових напрямів розвитку бізнесу. Слід також враховувати, що ситуація з пандемією COVID-19 та карантином стала каталізатором для розвитку та поширення максимально прикладних та утилітарних проєктів у сфері Інтернет-торгівлі, віддаленої роботи. Все це вказує на актуальність та необхідність використання перспективних цифрових інформаційних блокчейн технологій. Саме за допомогою блокчейну можна оцінити ризики втрати релевантної інформації, мінімізувати їх, застосовувати та розвивати найефективніші в кожному конкретному випадку алгоритми, в т.ч. й задля контрольованості та прозорості фінансових операцій. 


\section{Аналіз останніх досліджень і публікацій}

Питання застосування та розвитку блокчейну знаходяться у колі наукових інтересів багатьох вітчизняних та іноземних фахівців, обговорюються у ділових спільнотах, форумах, перебувають у площині державного регулювання. Ця тема досліджувалася у роботах C. Накамото [1], D. Tapscott, A. Tapscott [3], О. Лапко, О. Солосіч [6], О. Діб, К.-Л. Брусміче, А. Дюран, Е. Теа [7], П. Вінья [9] та інших науковців і професіоналів.

\section{Виділення невирішених раніше частин загальної проблеми, яким присвячусться стаття}

Незважаючи на значну кількість наукових та фахових досліджень за даним напрямом, незначні напрацювання в нормативній площині та перспективність розвитку технології блокчейн для України вказують на актуальність та необхідність додаткових напрацювань.

\section{Формулювання цілей статті}

Метою статті є вивчення стану використання блокчейн-технологій у сфері державного управління, визначення ключових напрямів розвитку блокчейну та його впливу на розвиток різних галузей економіки та сфер діяльності в Україні.

\section{Виклад основного матеріалу}

Технологію блокчейн винайшли два вчені Стюарт Хабер та У. Скотт Сторнетта. У 1991 році вони створили програмне забезпечення для цифрових документів із мітками часу. Саме їх вважають основоположниками технології блокчейн [1]. Наприкінці 2008 року Сатоші Накамото опублікував технічний документ «Біткоїн: однорангова електронна готівкова система», в якому представив світу децентралізовану валюту - це було народження біткоїна, а також задля цього було запропоновано новий принцип реєстрації транзакцій - Блокчейн 1.0. На сьогодні вже існує третє покоління технології блокчейн, яке знаходиться ще в процесі розвитку, але вже ведеться активна робота над рішеннями, здатними зробити переворот у цій галузі.

На сьогодні ідея блокчейну полягає в тому, що він може бути застосований при підписанні складних угод, які в цілому формують так звані рахунки-фактури. Сутність такої ідеї полягає в автоматизованій системі розрахунків за послугами (наприклад, сплати за доставку товару). При цьому будуть відслідковуватися всі попередні транзакції, а також буде створений цифровий ідентифікатор посвідчення особи. Через блокчейн формується спеціальна структура, яка проводить запис всіх операцій блок транзакцій - та містить дані про транзакції, дерево їх хешів та заголовки з даними, які містять хеші попереднього блоку. Слід також зазначити, що кожен наступний блок підтверджує попередній. Для того щоб така транзакція мала статус «підтвердженої», іiі потрібно сформувати в новий блок, разом 3 цим перевіривши іiі підпис та формат, а також необхідно здійснити контроль попередніх блоків. У такому випадку всі блоки стають в один ряд, формуючи цілісну систему транзакцій [3].

Світове поширення блокчейну значне. Його використовують такі країни, як США, Німеччина, Франція, Естонія, Китай, Україна та ін. 3 розвитком блокчейну було створено Міжнародною організацією зі стандартизації (ISO) комітет щодо розробки міжнародних стандартів технології блокчейн.

США $є$ однією із найбільш потужних країн даного процесу. Саме в цій країні розповсюджені основні біржові фонди, хедж-фонди та криптовалютні компанії, які використовують блокчейн. Крім того блокчейн використовується у фінансовому, земельному, військовому, політичному секторах та секторах нерухомості, у сфері промислового харчування, медицини, фармацевтичній та податковій діяльності. Правове регулювання здійснюється тут таким чином, що операції, пов'язані 3 платіжним засобом, перебувають під наглядом служби внутрішніх доходів, крім того основним регулятором є Державна комісія 3 цінних паперів та бірж [5].

Урядом Німеччини у 2019 р. було прийнято комплексну стратегію Blockchain, яка сприяє зменшенню ризиків, пов'язаних з впровадженням цієї технології.

В Естонії, яку на сьогодні вважають найбільш цифровою країною, вибудувана цифрова електронна інфраструктура за допомогою програми е-Estonia (сіть X-Road), а цілісність даних забезпечує технологія блокчейн. Вона має ряд цифрових функцій, а саме дає змогу голосувати, вести документацію у сфері медицини та проводити розрахунки онлайн, що пов'язані з податками. Регулювання тут здійснює фінансова поліція Естонії.

Уряд OAE з IBM та ConsenSys проводить співпрацю щодо цифровізації, яка повинна бути впроваджена на території всієї держави. Переконання цих компаній свідчать про те, що такий проєкт може спростувати думку щодо перевірки ідентифікаційних даних, а також дозволить оцифровувати й відслідковувати фінансову діяльність, сферу медичних послуг, а також інші різноманітні контракти [6].

Японія широко розповсюджує цифрові технології. В рамках стратегії “Безготівкове суспільство” в цій країні використовується правове регулювання, яке дозволяє здійснювати криптовалютні розрахунки. Контроль за криптобіржами здійснюють державні органи, а віртуальні активи повинні бути в обов'язковому порядку зареєстровані в Агентстві фінансових послуг Японії. Проте, за прогнозами PricewaterhouseCoopers, у 2021-2023 роках Китай займе лідируючу позицію. 
Однією з країн, де цифрові технології носять зміст нейтрального характеру, є Великобританія. Блокчейн-технології тут не досить поширені, а нагляд за такими процесами здійснює Управління фінансового регулювання та нагляду. Дана ситуація спрямована на те, щоб уникнути використання цифрових технологій заради шахрайства, відмивання грошей чи загальним протидіям закону. Натомість Великобританія широко використовує блокчейн у сфері створення штучного інтелекту, а також вносить потужні наукові розробки в сучасні нанотехнології.

У світі блокчейн використовується переважно в бізнесі й великих компаніях. Більшість суб' єктів господарювання вивчають та впроваджують цифровізовані технології в процес управління не тільки фінансової діяльності, а й виробничої. На побутовому рівні блокчейн тісно пов'язаний з криптовалютами, i, в першу чергу, 3 найбільш відомою 3 них - біткоїн. Справді, блокчейн $є$ технологічною основою криптовалют, але сфера його застосування набагато ширша. Технології блокчейну наразі можуть застосовуватися в будь-якій сфері. Наприклад, у сфері нерухомості. Можна проводити в електронний спосіб купівлю-продаж нерухомості, таким чином всі необхідні дані про власників зберігаються та накопичуються, а процес укладання договорів значно спрощується. Іншими словами, це дозволяє використовувати блокчейн як документальне свідчення або підтвердження передачі цифрових активів (біткойнів або іншої цифрової валюти). У сфері авторського права та особистих даних. Незмінність дозволяє використовувати блокчейн i як метод доказу відповідності процесів нормативним вимогам - запис усіх дій та отриманих результатів у ланцюжку блоків може бути аудиторським журналом для регулюючих органів [10].

Блокчейн може також використовуватися у галузі охорони здоров'я, медицини та фармацевтиці. Він застосовується для управління електронними медичними картами, ланцюжками поставок ліків, для боротьби з контрафактом, контролю за розподілом донорських органів, проведення клінічних та біомедичних досліджень, віддаленого моніторингу пацієнтів, покращення процедур страхування та виставлення рахунків, а також аналізу медичних даних.

Провідну роль відіграє цифровізація освітнього процесу. Якщо багато освітніх закладів перейдуть на прозору документацію (дипломи, академічні довідки тощо), використовуючи блокчейн або подібні захищені технології, шахраїв у цій сфері поменшає, а також можна буде позбутися ручних перевірок паперових документів, бо саме завдяки впровадженням штучного інтелекту буде проводитися автоматичний контроль паперів.

Цифровізація може бути застосована й у різних фінансових, банківських установах та підприємницькій діяльності. Якщо проаналізувати банківську діяльність, то банки служать для безпечного зберігання та передачі активів, що мають цінність. Блокчейн, захищений цифровим реєстром, може виконувати ці функції.

Міжнародні бухгалтерські корпорації, зокрема компанії “Великої четвірки”, досліджують питання щодо можливості застосування блокчейну в процесі ведення обліку та аудиту, при цьому діяльність самих бухгалтерів зміститься в напрямі формування облікової політики, правильної класифікації та інтерпретації подій, а також застосування професійних суджень. Враховуючи це, представникам бізнесу може бути цікаві можливі напрями застосування блокчейну в бухгалтерському обліку, які дозволять знизити витрати на його ведення та збільшити цінність облікової інформації.

За даними дослідження Gartner, на стадію промислового впровадження у 2020 році перейшли $14 \%$ корпоративних блокчейн-проєктів, тоді як у 2019 році ця частка становила лише 5 \%. Виходячи 3 цього, можна зробити висновок, що ріст корпоративного блокчейну набирає неабиякі обороти та поширення у більшості сфер діяльності [8]. За прогнозами Всесвітнього економічного форуму у Давосі до 2027 року $10 \%$ світового ВВП буде зберігатися в мережах блокчейн.

На сьогодні Україна входить до 14 країн-лідерів, які використовують блокчейн-технології, а також до десятки країн, де ці технології використовуються на державному рівні, що є досить позитивним фактом.

Характерним явищем для України $є$ те, що блокчейн найчастіше використовується у галузі високотехнологічних підприємств (Fintech), які конкурують 3 постачальниками традиційних послуг фінансового сектору економіки. Також на побутовому рівні блокчейн тісно пов'язаний з обігом криптовалют.

Розвиток цієї технології за даними Ассоціації Блокчейн України (АБУ) бере початок у 2014 р. Сьогодні ж в блокчейн індустрії України існує вже близько ста компаній і проєктів. Активна спільнота, яка включає компанії-засновники, приватних підприємців, експертів та ентузіастів галузі, налічує понад 350 учасників, кожного тижня відбувається захід присвячений питанням блокчейну та криптовалютам.

За даними АБУ у 2019 р. в Україні близько 200 криптокомпаній та блокчейн-компаній, 3 них 78 \% компаній орієнтовані як на український, так і на світовий ринки, 16\% лише на зовнішні ринки і лише одна компанія виключно на український ринок [4].

Асоціація займається питаннями координації та здійснення проєктів для розвитку індустрії та підвищення рівня освіченості широкої аудиторії в розумінні технології блокчейну та природи криповалют.

Серед перших пілотних проєктів з використанням цієї технолгії можна відмітити: електронні земельні аукціони, робота Державного земельного кадастру, Державного реєстру речових прав на нерухоме майно та Система електронної торгівлі арештованим майном (СЕТАМ). Вперше цю технологію в Україні у 2015 р. було введено через впровадження децентралізованої електронної системи аукціонів державного 
майна E-Auction 3.0. Метою даної платформи є підтримка некорумпованого, прозорого процесу приватизації державної та регіональної власності, землі та підприємств. Так, ключовим моментом реалізації стало підписання Меморандуму про розвиток державних електронних аукціонів на Blockchain.

Вже у 2016 р. в Україні відбувся перший аукціон блокчейн: Фонд державного майна України розпочав продаж держмайна через електронну торгову систему OpenMarket. Кожний бажаючий через цю технологію може перевірити хронологію подій, які відбувалися під час аукціону.

У 2019 р. цей проєкт було визнано одним 3 найкращих на вітчизняному ринку Fintech за останнє десятиріччя. У 2021 р. Україна зробила велику ставку на активізацію криптовалюти, що відповідно передбачає і розвиток даної технології. Було ухвалено Закон про легалізацію та регулювання біткоіну.

У 2021 p. Таскомбанк і фінтех-компанія Віtt запустили пілотний проєкт електронних грошей на блокчейні Stellar, щоб проаналізувати потенціал використання технології блокчейн при випуску електронної гривні. Проєкт реалізується під контролем Національного банку України (НБУ) та за підтримкою Міністерства цифрової трансформації України та передбачає використання електронних грошей для програмованих виплат заробітної плати працівникам ДП «Дія», р2р-розрахунків та розрахунків 3 мерчантами.

За очікуванням Закон про платіжні послуги, який регулюватиме обіг цифрових грошей та майбутній випуск цифрової валюти під егідою НБУ, набуде чинності у 2022 році.

Важливим фактором становлення та використання блокчейн-технологій в Україні може стати аналіз популярності пошукових запитів користувачів за цією темою в мережі Інтернет (рис. 1).

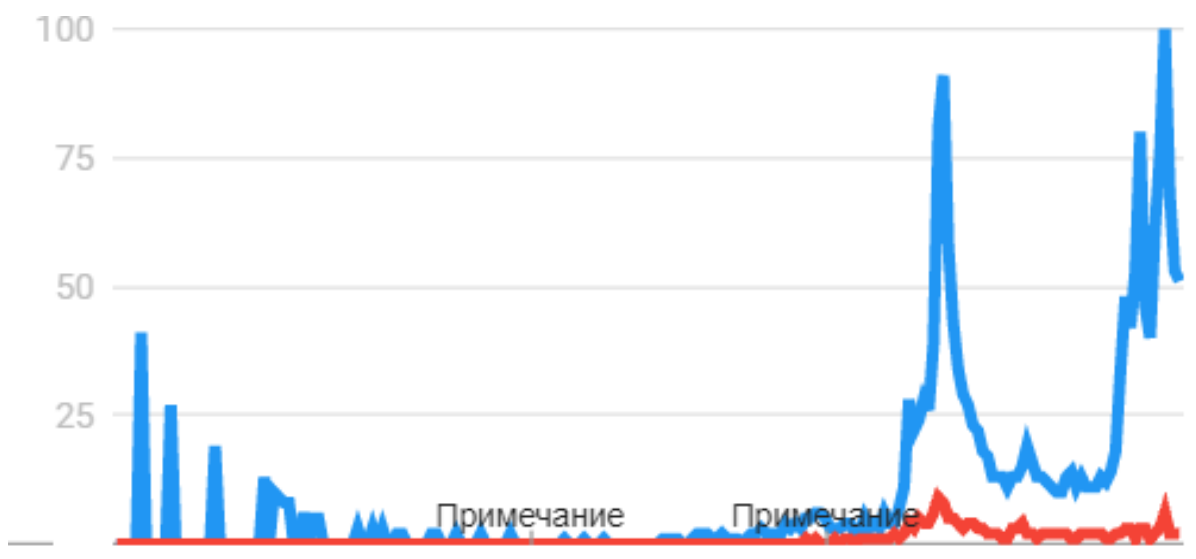

Рис. 1. Порівняння кількості пошукових запитів за темами «криптовалюта» та «блокчейн» за період 2004-2021 pp. Джерело: згенеровано за допомогою сервісу Google Trends

Так, нами було проведено аналіз двох пошукових запитів - «криптовалюта» та «блокчейн». Якщо порівнювати між собою ці поняття, то з рис. 1 бачимо, що спочатку зароджувалася та досліджувалася в Україні криптовалюта, а потім уже з'являється популярність до технологій блокчейну.

Слід відмітити, що інтерес українців до криптовалюти постає з початком 2000-х років. Так, за даними сервісу Google Trends, станом на 1 січня 2004 року показник популярності пошукових запитів категорії «криптовалюта» в мережі Інтернет становив за 100-бальною шкалою - 41 бал. Це свідчить про те, що рівень інтересу населення до цифрових грошей почав стрімко зростати. Подальші роки були обумовлені спадом популярності криптовалюти - до 2017 року нею майже ніхто не цікавився. Але з середини 2017 року криптовалюта знову набирає обертів в Україні - i це не дивно, адже саме в цей час набуває розвитку сфера цифровізованих технологій та електронної валюти. Найбільш стрімко розвивалася криптовалюта в жовтні 2021 року - тут популярність сягає максимального значення - 100 балів, що майже в 2,5 разів більше ніж в 2004 році.

Українці є одними із найзапекліших користувачів криптовалют у світі, посідаючи четверте місце у рейтингу Global Crypto Adoption Index, складеному компанією Chainalysis. Щорічно українці отримують та відправляють криптовалюту на $\$ 8$ млрд, а обсяг транзакцій із нею за один день становить близько $\$ 150$ млн, перевищуючи обсяг міжбанківських обмінів у фіатній валюті.

Наперекір цьому, саме технологія блокчейн $є$ не зовсім популярною та мало застосованою. Україна тільки починає розвиток своїх цифрових технологій. Проте, з поширенням електронних грошей, рівень обізнаності населення в сфері блокчейну починає зростати, та, ймовірно, що Україна буде розвиватися та застосовувати технологію блокчейн уже в найближчі роки більш активно. Отже, за результатами проведеного аналізу можна зробити висновок про підвищення зацікавленості до цієї теми в останній час, що, маємо сподівання, вплине і на активізації процесу використання самої технології.

В поданій нижче таблиці 1 наведено основні сильні та слабкі сторони застосування блокчейну в різних сферах, а також охарактеризовано його потенційні можливості та загрози. 
Таблиця 1

SWOT-аналіз використання блокчейн-технологій в управлінській діяльності різних сфер в Україні

\begin{tabular}{|l|l|l|l|}
\hline \multicolumn{1}{|c|}{ Сильні сторони } & \multicolumn{1}{|c|}{ Слабкі сторони } & \multicolumn{1}{|c|}{ Можливості } & Загрози \\
\hline - спрощення процесу & - відсутність єдиної & - впровадження блокчейн- & через брак досвіду та \\
управління інформацією; & стандартизованої системи щодо & технологій зможе змінити & єдного підходу досягти \\
- публічність та & блокчейн-технологій; & підходи до управлінської & бажаного результату буде \\
прозорість; & - відсутність кваліфікованого & діяльності (наприклад, & надто непросто; \\
- висока захищеність від & персоналу; & спростити документообіг); & - також не є виключенням \\
хакерських атак; & - недосконалість законодавства та & - високорівневе програмування & хакерські атаки. Блокчейн- \\
- можливість зекономити & нормативних актів; & та штучний інтелект & технології хоч і проходять \\
час та потенційні & - неможливість впровадити & передбачатиме те, що & шифрування та кодування, \\
ресурси; & цифровізоване управління даними & управлінські рішення будуть & але вірогідність взлому \\
- висока цифровізація & через слабкий зв’язок та часті & застосовуватися переважно без & присутня. \\
отримання (надання) & перебої мережі Інтернет по & втручання людей, тобто & \\
різноманітних послуг & Україні. & автоматично & \\
\hline
\end{tabular}

Джерело: побудовано на основі загальнодоступної інформації та її безпосереднього аналізу

Якщо зосередити увагу саме на управлінській діяльності різних галузей, то, безумовно, блокчейн може змінити та спростити ситуацію 3 документообігом, реєстрацією та передачею активів, веденням облікових даних та, взагалі, може спростувати стандартні «ручні» підходи в цілому, втручання людей буде мінімізовано.

Проте, існує ряд недоліків та можливих загроз. Справа в тому, що в світі не існує стандартизованих підходів щодо цифровізованих технологій блокчейну, а в Україні думка, щодо такої діяльності тільки починає досліджуватися і є малоефективною. Для того, щоб Україна повністю або частково застосувала свої цифровізовані технології, знадобиться дуже багато часу. Основним недоліком такого прояву є нестача кваліфікованого персоналу в цій сфері, відсутність чітких законодавчих розмежувань щодо блокчейну та, найголовніше, відсутність високоякісного Інтернет-покриття. Так, безперечно, високорозвинені міста України зможуть застосовувати ці технології, але інші населені пункти (райони, міста 3 меншим економічним значенням, територіальні громади, села тощо) не мають високоякісного швидкого Інтернету.

\section{Висновки $з$ дослідження і перспективи подальших розвідок у цьому напрямі}

Подальше використання блокчейн технологій для нашої країни дозволить забезпечити стрімке зростання економіки, підвищення рівня соціального життя, вирішення різноманітних проблем та ін. Проте, щоб повномірно користуватись можливостями блокчейну, необхідно внести зміни до діючого законодавства України.

\section{Література}

1. Накамото С. Біткоїн: однорангова електронна система готівки. URL: https://bit coin.org/bitcoin.pdf

2. PwC Global Blockchain Survey. PricewaterhouseCoopers. 2018. URL: https://www.pwc.com/jg/en/ publications/blockchain-is-here-next-move.html

3. Tapscott D., Tapscott A. Blockchain revolution: how the technology behind bitcoin is changing money, business, and the world. 2016. URL: books.google.com

4. Overview of the blockchain industry in Ukraine. Blockchain Association of Ukraine. May 2019, Kyiv. URL: https://bau.ai/wp-content/uploads/2019/05/Overview-of-the-blockchain-industry-in-Ukraine.pdf.

5. What is Blockchain Technology? A Step-by-Step Guide For Beginners. URL: https://blockgeeks.com/ guides/what-is-blockchain-technology.

6. Лапко О.О., Солосіч О. С. Технологія блокчейн: поняття, сфери застосування та вплив на підприємницький сектор. Бізнес Інформ. 2019. № 6. С. 77-82.

7. Діб О., Брусміче К.-Л., Дюран А., Теа Е. Блокчейн для підприємства: огляд, можливості та виклики. URL: https://www.researchgate.net/publication/322078519_Blockchain_for_enterprise_Overview_ Opportunities_and_Challenges.

8. Денис О.Б. Перспективи використання технології Blockchain на фінансових ринках. Причорноморські економічні студії. 2019. Вип. 45. С. 140-144. URL: http://nbuv.gov.ua/UJRN/bses_/ 20194528.

9. Вінья П. Епоха криптовалют. Як біткони і блокчейн змінюють світовий економічний порядок. НьюЙорк: Pan Books Limited, 2017. 432 с. 07/29878823/.

10. Технологія блокчейн. Як це працює в бізнесі. 2017. URL: https://minfin.com.ua/ua/2017/09/

\section{References}

1. Nakamoto S. Bitkoin: odnoranhova elektronna systema hotivky (2020), available at: https://bit coin.org/bitcoin.pdf

2. PwC Global Blockchain Survey. PricewaterhouseCoopers (2018), available at: https://www.pwc.com/jg/en/ publications/ blockchain-is-here-next-move.html

3. Tapscott D., Tapscott A. (2016). Blockchain revolution: how the technology behind bitcoin is changing money, business, and the world, available at: books.google.com 
4. Overview of the blockchain industry in Ukraine. Blockchain Association of Ukraine. May 2019, Kyiv, available at: https://bau.ai/wp-content/uploads/2019/05/Overview-of-the-blockchain-industry-in-Ukraine.pdf.

5. What is Blockchain Technology? A Step-by-Step Guide For Beginners (2020), available at: https://blockgeeks.com/guides/what-isblockchain-technology.

6. Lapko O.O., Solosich O. S. (2019). Tekhnolohiia blokchein: poniattia, sfery zastosuvannia ta vplyv na pidpryiemnytskyi sektor. Biznes Inform. Vyp. 6. pp. 77-82.

7. Dib, O., Brusmiche, K.-L., Diuran, A., Tea, E. Blokchein dlia pidpryiemstva: ohliad, mozhlyvosti ta vyklyky, available at: https://www.researchgate.net/publication/322078519_Blockchain_for_enterprise_Overview_Opportunities_and_Challenges.

8. Denys O.B. (2019). Perspektyvy vykorystannia tekhnolohii Blockchain na finansovykh rynkakh. Prychornomorski ekonomichni studii. Vyp. 45. pp. 140-144, available at: http://nbuv.gov.ua/UJRN/bses 20194528

9. Vinia P. (2017). Epokha kryptovaliut. Yak bitkony i blokchein zminiuiut svitovyi ekonomichnyi poriadok. NiuIork: Pan Books Limited.

10. Tekhnolohiia blokchein. Yak tse pratsiuie v biznesi (2017), available at: https://minfin.com.ua/ua/2017/09/07/29878823/

Надійшла / Paper received: 22.11.2021

Надрукована / Printed: 30.12 .2021 